\title{
Chromosomal localization and activity of nucleolar organizer regions in the dog (Canis familiaris)
}

\author{
Aldona Pieńkowska, Marek Świtoński* \\ Department of Genetics and Animal Breeding, Agricultural University of Poznan, \\ Wolyńska 33, 60-637 Poznan, Poland
}

(Received 2 June 1997; accepted 5 December 1997)

\begin{abstract}
Using fluorescent in situ hybridization on Q-banded chromosomes, nucleolar organizer regions (NORs) were localized on canine chromosomes 7qter, 17qter, Yqter and also terminally on a small autosome, not yet included in the dog standard karyotype. The analysis of NOR activity was carried out on Ag-I stained metaphases originating from 27 individuals (10 males and 17 females). The mean number of silver stained NORs was 6.0 in males and 5.3 in females and the modal number was 7 and 6, respectively. Interindividual variability of the mean and modal numbers of silver NORs was observed. The lowest individual mean number of NORs was 4.2 and the highest 7.0 , and the modal value ranged from 4 to 7 . (C) Inra/Elsevier, Paris
\end{abstract}

NOR / dog / fluorescent in situ hybridization / silver staining

Résumé - Localisation chromosomique et activité d'organisateurs nucléolaires chez le chien (Canis familiaris). Les organisateurs nucléolaires (NORs) des chromosomes visualisés en bandes $\mathrm{Q}$ ont été localisés par hybridation fluorescente in situ sur les chromosomes canins 7qter, 17qter, Yqter et ainsi qu'à l'extrémité d'un petit autosome, qui n'est pas encore inclus dans le caryotype standard du chien. L'activité des organisateurs nucléolaires a été mise en évidence sur des métaphases colorées par l'Ag-I provenant de 27 individus (10 mâles et 17 femelles). Il a été trouvé que le nombre moyen d'organisateurs nucléolaires colorés par l'argent était de 6 chez les mâles et de 5,3 chez les femelles et que la valeur modale était respectivement 7 et 6 . Une variabilité interindividuelle du nombre moyen et de la valeur modale a été observée pour les organisateurs nucléolaires colorés par l'argent. Le nombre moyen le plus bas d'organisateurs nucléolaires chez un individu était de 4,2 et le plus élevé de 7, la valeur modale se situant entre 4 et 7 . (C) Inra/Elsevier, Paris

NOR / chien / hybridation fluorescente in situ / coloration par l'argent

${ }^{*}$ Correspondence and reprints 


\section{INTRODUCTION}

In the nucleolar organizer regions (NORs), there are genes for $5.8 \mathrm{~S}, 18 \mathrm{~S}$ and $28 \mathrm{~S}$ ribosomal RNA. These regions can be visualized by the silver staining method or in situ hybridization with the use of appropriate molecular probes.

Silver staining reveals transcriptionally active NORs, since precipitation of metallic silver occurs only in the regions where acid proteins are present [15]. On the other hand, in situ hybridization visualizes all (active and inactive) NORs which are present in a karyotype.

In the family Canidae, chromosomal localization of NORs is known for two species with an established standard karyotype: the blue fox, Alopex lagopus [8] and the silver fox, Vulpes fulvus [9]. Recently, a partial standard karyotype of the dog, comprising the 21 largest autosome pairs and sex chromosomes, was established [18]. This made the development of the physical mapping of the canine genome possible.

The objective of the present study was the chromosomal localization of NORs in the dog karyotype and the analysis of their activity. This study is a contribution to a joint effort within the DogMap programme established in 1993, which aimed at the development of a low density marker map of the dog genome [13].

\section{MATERIAL AND METHODS}

The somatic chromosomes were studied in cultured peripheral blood lymphocytes collected from 27 crossbred dogs.

Chromosomal localization of NORs was carried out with the use of fluorescent in situ hybridization (FISH) on pre-identified Q-banded chromosomes. For FISH experiments, a $28 \mathrm{~S}$ rDNA human probe [16] was labelled with the use of biotin16-dUTP. Hybridization of the probe was carried out without competitor DNA and the Avidin-FITC system was applied to detect the hybridization signals. Chromosomes were identified according to the nomenclature presented in the Gbanded partial standard karyotype [18]. It was assumed that Q-banding patterns of dog chromosomes were similar to the GTG ones.

The activity of NORs was studied for 27 individuals ( 10 females and 17 males). For each individual 8 to 10 silver stained metaphases were analysed. In the case of a single female, 12 metaphases were recorded. Active NORs were visualized by the Ag-I banding technique [3].

\section{RESULTS}

FISH experiments revealed NORs on three autosome pairs (figure 1) and on the Y chromosome. The Q-banding pattern indicated that NORs were localized in the terminal part of the $q$ arms of chromosome pairs: 7 and 17. The third chromosome pair, also bearing NORs in the terminal part of the q arm, belongs to a group of small autosomes not yet included in the canine standard karyotype. The banding pattern of this chromosome is shown in figure $1 \mathrm{~A}$. In the male karyotype, a NOR occurred also in the terminal part of the long arm of the $\mathrm{Y}$ chromosome. 


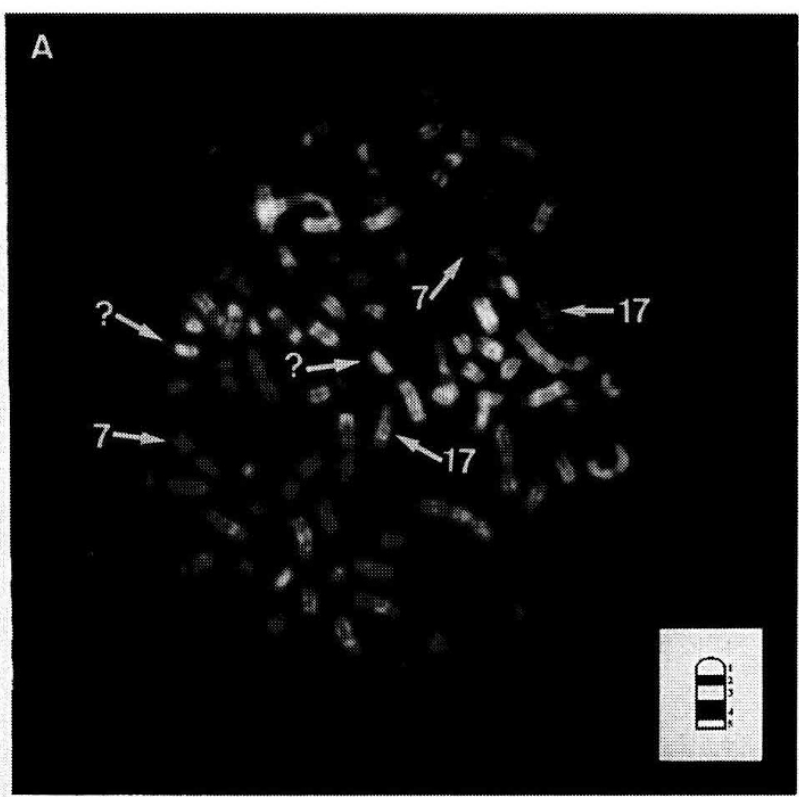

B
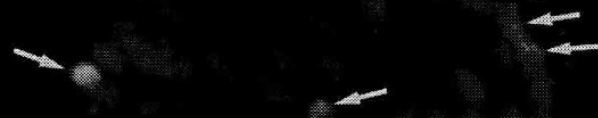

$\longrightarrow$

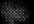

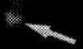

Figure 1. A Q-banded metaphase of a female. Insert shows a diagramatic representation of the Q/G-banding pattern of the small autosome $(? \rightarrow)$ bearing NORs; B fluorescent in situ hybridization of the plasmid $28 \mathrm{~S}$ rDNA probe on the same metaphase. NOR-bearing chromosomes are indicated by arrows. 
A detailed analysis of the silver deposit distribution on the chromosomes of 27 individuals showed that all seven NORs were transcriptionally active (table $I)$. The activity of NORs was similar in all three autosome pairs. The majority of metaphases (approx. $79 \%$ ) demonstrated that both NORs of a chromosome pair were active. The NOR on the Y chromosome showed a similar pattern of activity.

Table I. Distribution of silver stained NORs on canine chromosomes.

\begin{tabular}{|c|c|c|c|c|}
\hline \multirow[t]{2}{*}{ Chromosome } & \multirow{2}{*}{$\begin{array}{l}\text { Total number } \\
\text { of metaphases }\end{array}$} & \multicolumn{2}{|c|}{ Silver deposits on } & \multirow{2}{*}{$\begin{array}{c}\text { Lack of } \\
\text { silver deposits }\end{array}$} \\
\hline & & Both chromosomes & One chromosome & \\
\hline 7 & 266 & $202(76 \%)$ & $56(21 \%)$ & $8(3 \%)$ \\
\hline 17 & 266 & $222(83 \%)$ & $39(15 \%)$ & $5(2 \%)$ \\
\hline Unidentified & 266 & $204(77 \%)$ & $53(20 \%)$ & $9(3 \%)$ \\
\hline $\mathrm{Y}$ & 164 & - & $130(79 \%)$ & $34(21 \%)$ \\
\hline
\end{tabular}

Analysis of the number of silver NORs among the 27 dogs showed a wide range of variation (table $I I)$. The individual mean number of silver deposits varied from 4.2 to 6.0 in females and from 4.8 to 7.0 in males. The mean number of NORs calculated for all males was higher (6.0) than for females (5.3). This was mainly due to the NOR activity on the Y chromosome. Similar variability was found for the modal number, i.e. the most frequently observed number of silver NORs.

Table II. Interindividual variability of the number of silver NORs.

\begin{tabular}{lcccccc}
\hline Sex & $\begin{array}{c}\text { No. of } \\
\text { animals }\end{array}$ & \multicolumn{2}{c}{ Mean $(\bar{x})$} & & \multicolumn{2}{c}{ Modal number } \\
\cline { 3 - 4 } \cline { 6 - 7 } \cline { 6 - 7 } & & All individuals & $\begin{array}{c}\text { Interindividual } \\
\text { range }^{\mathrm{a}}\end{array}$ & & All individuals & $\begin{array}{c}\text { Interindividual } \\
\text { range }^{\mathrm{a}}\end{array}$ \\
\hline Females & 10 & $5.3(1.06)^{\mathrm{b}}$ & $4.2-6.0$ & & 6 & $5-6$ \\
Males & 17 & $6.0(1.13)^{\mathrm{b}}$ & $4.8-7.0$ & & 7 & $4-7$ \\
\hline
\end{tabular}

a The range shows the lowest and the highest individual mean or modal number of silver NORs found among studied animals; ${ }^{\mathrm{b}}$ the standard deviations are indicated in parentheses.

\section{DISCUSSION}

Nucleolar organizer regions in the dog karyotype were studied by several authors. Unfortunately, the obtained results were not consistent. Several reports showed the occurrence of silver stained NORs in the terminal part of the long arms of three autosome pairs and also on the $\mathrm{Y}$ chromosome $[6,11,12]$. Other reports based on 
silver staining suggested, however, a higher number of chromosome pairs bearing NORs $[1,5,14]$. Recently, the in situ hybridization approach was applied. Using a $18 \mathrm{~S}+28 \mathrm{~S}$ rDNA human probe, Mäkinen et al. [10] localized NORs on G-banded chromosomes 7, 17, a small unidentified autosome and the $\mathrm{Y}$ chromosome. Also, Fischer et al. [2] assigned NORs by the FISH method in a female karyotype to three G-banded autosome pairs: 7, 8 and a small unidentified autosome. Our study, using the QFQ/FISH approach, confirmed the results obtained by Mäkinen et al. [10]. Moreover, we present the $\mathrm{Q} / \mathrm{G}$ pattern of the small autosome, not yet included in the canine standard karyotype.

The analysis of silver stained metaphases of 27 individuals revealed high transcriptional activity of the NORs. Similar results were presented by Pathak et al. [12] for a single male and Graphodatsky [4] for three males and one female. However, in the latter study the Y chromosome was not indicated as a NOR-bearing one. Our study also showed that activity of NORs demonstrated a wide interindividual variability. The individual mean number of NORs ranged between 4.2 and 7.0 in this study.

The distribution of silver stained NORs has also been analysed in other canids. It was found that NORs were present on seven chromosomes, including the $Y$ chromosome, in the raccoon dog, Nyctereutes procyonoides [7]. In the karyotype of the silver fox, Vulpes fulvus, there are three autosome pairs bearing NORs which are localized terminally on chromosomes $8 q, 9 q$ and $13 q[8]$. The analysis of their activity showed that the mean number of silver stained NORs was 5.2 , but the modal number was 6 [17]. The highest number of NORs was found in the karyotype of the blue fox, Alopex lagopus. There are six chromosome pairs with NORs. They were localized terminally on the short arm of chromosomes 13, 15, 17, 18, 20 and $22[9]$.

\section{ACKNOWLEDGMENTS}

The rDNA probe was kindly provided by Professor Dr G. Stranzinger and Dr R. Fries from the Swiss Federal Institute of Technology, Zurich. This study was supported by The Committee for Scientific Research, Poland, grant: 5S3041206.

\section{REFERENCES}

[1] Delgado J.V., Moreno-Milan M., Alonso J., Alonso A., Rodero A., Distribution of NOR activity regions in dogs, Proc. 8th Eur. Colloq. Cytogenet. Domest. Anim., Bristol, 1988, pp. 129-133.

[2] Fischer P.E., Holmes N.G., Dickens H.F., Thomas R., Binns M.M., Nacheva E.P., The application of FISH technique for physical mapping in the $\operatorname{dog}$ (Canis familiaris), Mammal Genome 7 (1996) 37-41.

[3] Goodpasture C., Bloom S.E., Visualization of nucleolar organizer regions in mammalian chromosomes using silver staining, Chromosoma 55 (1975) 37-50.

[4] Graphodatsky A.S., Comparative cytogenetics of three canids species (Carnivora, Canidae). III. Distribution of nucleolar organizer regions, Genetika (USSR) 19 (1983) 778-783.

[5] Howard-Peebles P.N., Howell W.M., Nucleolus organizer regions of the canine karyotype, Cytogenet Cell. Genet. 35 (1983) 293-294. 
[6] Kopp E., Mayr B., Schleger W., Nucleolus organizer regions on chromosomes of the domestic dog, J. Heredity 73 (1982) 73.

[7] Mäkinen A., Fredga K., Banding analyses of the somatic chromosomes of Raccoon dog; Nyctereutes procyonoides, from Finland, Proc. 4th Eur. Colloq. Cytogenet. Domest. Anim., Uppsala, Swedish University of Agricultural Sciences, Uppsala, Sweden, 1980, pp. 420-430.

[8] Mäkinen A., Gustavsson I., Świtoński M., Takagi N., The standard karyotype of the blue fox (Alopex lagopus). Hereditas 103 (1985) 33-38.

[9] Mäkinen A., Kuokkanen M.T., Gustavsson I., Isakova G.K., Takagi N., The standard karyotype of the silver fox (Vulpes fulvus), Hereditas 103 (1985) 171-176.

[10] Mäkinen A., Zijlstra C., de Haan N.A., Mellink C.H.M., Bosma A.A., Genes encoding $18 \mathrm{~S}+28 \mathrm{~S}$ ribosomal RNA in the dog are located on three autosome pairs and the Y chromosome, Anim. Genet. 27 (suppl 2) (1996) 70.

[11] Mayr B., Geber G., Auer H., Kalat M., Schleger W., Heterochromatin composition and nucleolus organizer activity in four canid species, Can. J. Genet. Cytol. 28 (1986) 744-753.

[12] Pathak S., van Tuinen P., Merry D.E., Heterochromatin, synaptonemal complex, and NOR activity in the somatic and germ cells of a male domestic dog (Canis familiaris), Cytogenet Cell. Genet. 34 (1982) 112-118.

[13] Report from the First International DogMap Meeting, Animal Genetics 24 (1993) 399.

[14] Ronne M., Poulsan B.S., Shibasaki Y., NOR association in Canis familiaris. Genet. Sel. Evol. 23 (suppl. 1) (1991) 191-195.

[15] Schwarzacher H.G., Wachtler F., Nucleolus organizer regions and nucleoli, Hum. Genet. 63 (1983) 89-99.

[16] Sylvester J.E., Whiteman D.A., Podolsky R., Pozsgay J.M., Respees J., Schmickel R.D., The human ribosomal RNA genes: structure and organization of the complete unit, Hum. Genet. 73 (1986) 193-198.

[17] Świtoński M., B chromosomes in fox (Vulpes vulpes), their nature, distribution, inheritance and effects, Roczniki Akademii Rolniczej w Poznaniu 174 (1988) (in Polish).

[18] Świtoński M., Riemann N., Bosma A.A., Long S., Bartnitzke S., Pieńkowska A., Moreno-Milan M.M., Fischer P., Report on the progress of standardization of the G-banded canine (Canis familiaris) karyotype. Chrom. Res. 4 (1996) 306-309. 